\title{
Analisis Kepuasan Kerja Pegawai dengan Analisis Gap dan Kuadran Pada Pegawai PPSDM-BPPK-Kemenkeu
}

\author{
Daniel Pangaribuan' ${ }^{1}$ Pardomuan Robinson Sihombing ${ }^{2}$ \\ ${ }^{1}$ Kementerian Keuangan, ${ }^{2}$ Badan Pusat Statistik \\ e-mail: robinson@bs.go.id

\begin{tabular}{ccc}
\hline Diterima & Direvisi & Disetujui \\
$29-08-2021$ & $31-08-2021$ & $01-09-2021$
\end{tabular}

\begin{abstract}
Abstrak - Penelitian ini membahas kepuasan kerja pegawai pada pegawai PPSDM-BPPK-Kemenkeu. Adapun metode analisis yang digunakan adalah analisis gap dan kuadran analisis. Hasil yang didapattingkat kepuasan pegawai PPSDM masuk dalam kategori kurang puas dibawah 99 persen. Tingkat kesesuaian kepuasan kerja pegawai bernilai sempurna, berarti organisasi memberikan kepuasan kerja yang memenuhi apa yang dianggap penting oleh pegawai atau pelayanan telah memuaskan. Faktor kompensasi relatif sudah memberikan kepuasan kepada pegawai. Faktor promosi ini dalam diagram kartesius masuk di kuadran IV yaitu prioritas rendah. Sedangkan faktor rekan kerja merupakan faktor yang paling tinggi yang menunjang kepuasan kerja pegawai. Pegawai menganggap rekan kerja penting dan persepsi terhadap rekan kerja memuaskan. Adapun saran yang dapat diberikan adalah Agar PPSDM dan BPPK secara keseluruhan melakukan evaluasi terhadap kepuasan kerja pegawai PPSDM sehingga dapat meningkatkan kepuasan kerja pegawai.
\end{abstract}

Kata Kunci: gap, kuadran, kepuasan

Abstract - This study discusses employee job satisfaction at PPSDM-BPPK-Kemenkeu employees. The analytical methods used are gap analysis and quadrant analysis. The results obtained that the satisfaction level of PPSDM employees is in the less satisfied category below 99 percent. The level of employee job satisfaction deserves perfect, meaning that the organization's job satisfaction fulfills what is considered important by the employee or the service has been satisfactory. The relative compensation factor has given satisfaction to employees. This promotion factor in the Cartesian diagram is in quadrant IV, which is low priority. While the co-workers factor is the highest factor that supports employee job satisfaction. Employees consider co-workers important and perceptions of co-workers are satisfactory. The suggestions that can be given are that PPSDM and BPPK as a whole evaluate the job satisfaction of PPSDM employees so that they can increase employee job satisfaction.

Keywords: gap, quadrant, satisfaction

\section{PENDAHULUAN}

Kepuasan kerja merupakan faktor yang sangat penting bagi kehidupan setiap pegawai dalam pekerjaannya. Kepuasan kerja ini dikatakan sangat penting karena menurut teori persepsi nilai Colquitt et.al(2015), kepuasan kerja menyeluruh dipengaruhi oleh lima faktor kepuasan yaitu kepuasan atas kompensasi, kepuasan atas promosi, kepuasan atas supervisi, kepuasan atas rekan kerja dan kepuasan atas pekerjaan itu sendiri.

Pentingnya kepuasan kerja dalam kehidupan pegawai adalah karena sebagian besar dari waktu kehidupannya terlibat di dalam pekerjaan itu sendiri(Ardana, Mujiati, \& Utama, 2012).Pada sisilain,organisasi membutuhkan pegawai yang memiliki kepuasan kerja yang bagus. Dengan pegawai yang memiliki kepuasan kerja yang bagus, organisasi memiliki kesempatan yang besar untuk memberikan kepuasan kepada pemangku kepentingan lainnya (Mas'ud, 2004).Mengingat bahwa organisasi adalah kumpulan dari anggota yang memiliki tujuan yang sama, maka unsur pegawai sebagai anggota organisasi menjadi unsur yang paling penting.

Beberapa manfaat dari kepuasan kerja pegawai tehadap organisasi antara lain adalah bahwa kepuasan kerja pegawai dapat mengurangi perputaran pegawai, mengurangi kemungkinan mogok, mengurangi keterlambatan masuk kerja dan mengurangi efek negatif lainnya(Mutiara, 2004, ). Sebagaimana disebutkan oleh Colquitt et.al(2015), bahwa kepuasan kerja adalah wujud dari yang dirasakan tentang pekerjaan dan tentang yang dipikirkan tentang pekerjaan.

Tingkat kepuasan yang rendah atau ketidakpuasan kerja dapat berpengaruh negatif terhadap faktor lainnya. Menurut Batemen dan Snell (2015)ketidakpuasan kerja dapat mengakibatkan (1) tingginya perputaran pegawai, (2) tingginya 
ketidakhadiran kerja, (3) kurangnya rasa memiliki sesama pegawai, (4) tingginya pelanggaran hukum, (5) mogok, (6) pencurian, sabotasi,dan vandalism, (7) mental dan kesehatan jiwa yang buruk, (8) banyak yang dirugikan, (9) pelayanan pelanggan yang buruk, (10) rendahnya produktivitas dan keuntungan.

Dengan melihat pengaruh positif dan negatif dari unsur kepuasan kerja yang signifikan bagi pegawai dan organisasi, maka kepuasan kerja ini perlu menjadi perhatian untuk dikeloladan ditingkatkan(Sedarmayanti., 2001). Tingkat kepuasan kerja seorang pegawai dapat diukur dengan membandingkan antara harapan dan persepsinya sendiri terhadap lima unsur kepuasan kerja. Sehubungan dengan itu tingkat kepuasan kerja setiap pegawai dalam suatu organisasi dapat berbeda beda. Tingkat kepuasan pegawai akan tinggi apabila dia memiliki persepsi atas yang diterimanya lebih besar dari harapannya. Atau apabila pekerjaannya memberikan sesuatu yang memiliki nilai bagi pegawai tersebut. Pada saat yang sama pegawai lain dapat merasa bahwa yang mereka peroleh (persepsi) tidak sesuai dengan nilai yang mereka harapkan(Stephen \& Judge, 2015).

Di dalam organisasi birokrasi ada kemungkinan akan terdapat perbedaan kepuasan kerja antara lapisan pegawai. Misalnya kepuasan kerja seorang pelaksana dengan kepuasan kerja pejabat struktural akan berbeda. Tingkat kepuasan kerja pejabat struktural dengan pejabat fungsional juga kemungkinan akan berbeda(Sudriamunawar, 2006). Bahkan tingkat kepuasan antara tingkatan pejabat struktural juga dapat berbeda, karena kewenangan dan tanggung jawab masing-masing berbeda.

Pegawai PPSDM yang berjumlah 105 orang yang dapat dikategorikan kedalam beberapa kelompok, kemungkinan mendapatkan kepuasan kerja yang berbeda. Misalnya kepuasan kerja kelompok pejabat struktural, pelaksana dan fungsional, kemungkinan berbeda karena kompensasi, kesempatan promosi, rekan kerja, supervise dan jenis pekerjaan yang berbeda. Demikian juga kepuasan kerja kelompok menurut golongan II, golongan III dan golongan IV kemungkinan juga berbeda.

Dengan memperhatikan pentingnya kepuasan kerja pegawai pada PPSDM dalam rangka mengelola pelaksanaan tugas dan fungsinya secara efektif dan efisien, sangat perlu dilakukan analisis. Salah satu bentuk analisis yang dapat dilakukan adalah analisis gap antara harapan dan persepsi pada faktor yang memengaruhi kepuasan kerja para pegawainya yaitu kompensasi, promosi, rekan kerja, supervisi dan pekerjaan itu sendiri.

Sehubungan dengan uraian di atas, maka penelitian ini berjudul "Analisis Kepuasan Kerja Pegawai Dengan Analisis Gap dan Kuadran pada Pegawai PPSDM-BPPK-Kemenkeu".

\section{METODE PENELITIAN}

Populasi dalam penelitian ini adalah pegawai Pusat Pengembangan dan Pelatihan Sumber Daya Manusia (PPSDM) - Badan Pendidikan dan Pelatihan Keuangan (BPPK) Kementerian Keuangan. Jumlah pegawai yang menjadi populasi penelitian ini adalah 105 orang. Dengan mempertimbangkan jumlah populasi yang tidak terlalu besar yaitu 105 orang maka semuanya diambil sebagai sampel atau yang dikenal dengan sampel jenuh. Teknik pengumpulan data lapangan dalam penelitian ini menggunakan teknik kuesioner(Siregar, 2013). Menurut Muri (2014), kuesioner adalah suatu rangkaian pertanyaan yang berhubungan dengan topik tertentu yang diberikan kepada sekelompok individu dengan maksud untuk memperoleh data. Pengujian kuesioner dalam penelitian ini menggunakan skala likert dengan lima opsi jawaban.

Penelitian ini menggunakan metode survei dengan deskriptif eksplanatifdengan tujuan mendeskripsikan suatu kejadian atau fenomena tertentu. Menurut Sugiyono(2013) menyimpulkan bahwa metode penelitian survei adalah metode penelitian kuantitatif. Dalam penelitian ini terdapat enam variabel yaitu kepuasan kerja, kompensansi, promosi, rekan kerja, supervise dan pekerjaan itu sendiri.

Teknik analisis data menggunakan analisis gap (Gap Analysis). Analisis gap adalah metode untuk mengukur dan mengetahui kesenjangan (gap) antara kinerja suatu variabel dengan harapan terhadap variabel tersebut. Dalam penelitian initingkat kesenjangan kepuasan kerja pegawai PPSDMdiukur dengan membandingkan persepsi pegawai atas variable kepuasan kerja dengan harapan pegawai. Analisis gap terhadap kepuasan kerja pegawai PPSDM akan menggunakan dua perhitungan, yaitu mencari tingkat kesesuaian dan diagram cartesius(Uma \& Bougie, 2010).

Analisis tingkat kesesuaian $\left(\boldsymbol{T} \boldsymbol{X}_{i}\right)$ bertujuan untuk mengetahui tingkat kesesuaian antara persepsi variable $\left(\boldsymbol{X}_{i}\right)$ kepuasan dengan harapan pegawai $\left(\boldsymbol{Y}_{i}\right)$ PPSDM. Rumus yang digunakan untuk menghitung tingkat kesesuaian adalah:

$$
\begin{aligned}
& T K_{i}=\frac{\sum X_{i}}{\sum Y_{i}} \times 100 \% \text {..................... (1) } \\
& \text { Setelah tingkat kesesuaian diukur, }
\end{aligned}
$$
selanjutnya peneliti menganalisis lebih lanjut dengan memasukkan hasil yang diperoleh ke dalam diagram kartesius. Diagram kartesius adalah suatu bangun yang terdiri dari atas empat bagian yang dibatasi oleh dua buah garis yang berpotongan tegak lurus pada titik (X, Y). Garis X merupakan rata-rata tingkat pelaksanaan atau kepuasan kerja pegawai PPSDM atas seluruh faktor atau atribut.Garis $\mathrm{Y}$ adalah ratarata dari skor rata-rata tingkat kepentingan atau harapan seluruh faktor yang mempengaruhi kepuasan kerja pegawai PPSDM 


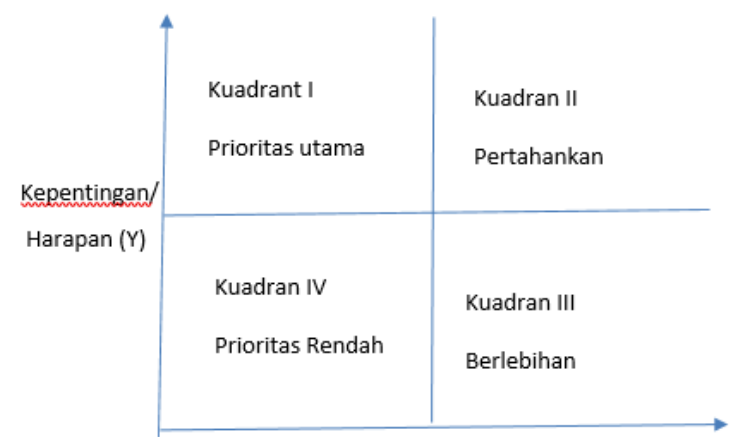

Persepsi Kinerja/Kenyataan (X)

Gambar 1. Diagram Kuadran Kartesius

Menurut Supranto (2006) diagram ini terdiri atas empat kuadran yaitu:

\section{Kuadran I (Prioritas Utama)}

Kuadran I memuat atribut/pernyataan yang dianggap penting oleh pegawai namun atribut/pernyataan tersebut belum sesuai dengan harapan pegawai. Tingkat kinerja dari atribut/pernyataan tersebut lebih rendah daripada tingkat harapan pegawai terhadap atribut/pernyataan tersebut. Atribut/pernyataan yang terdapat dalam kuadran ini menjadi prioritas untuk ditingkatkan kinerjanya supayakepuasan kerja pegawai dapat memuaskan.

\section{Kuadran II (Pertahankan Prestasi)}

Atribut/pernyataan ini memiliki tingkat harapan yang tinggi. Hal ini menunjukkan bahwa atribut/pernyataan tersebut penting untuk kepuasan kerja pegawai. Atribut/pernyataan dalam kuadran II ini wajib dipertahankan untuk waktu yang akan datang karena dianggap sangat penting/diharapkan dan hasilnya sangat memuaskan.

\section{Kuadran III (Prioritas Rendah)}

Atribut/pernyataan yang terdapat dalam kuadran ini dianggap kurang penting oleh pegawai dan pada kenyataannya persepsi pegawai tidak terlalu istimewa/biasa saja. Maksudnya atribut/pernyataan yang terdapat dalam kuadran ini memiliki tingkat harapan yang rendah dan persepsi pegawai juga rendah. Perbaikan terhadap atribut/pernyataan yang masuk dalam kuadran ini perlu dipertimbangkan kembali dengan melihat atribut/pernyataan yang mempunyai pengaruh terhadap manfaat yang dirasakan oleh pegawai itu besar atau kecil dan juga untuk mencegah atribut/pernyataan tersebut bergeser ke kuadran I.

\section{Kuadran IV (Berlebihan)}

Pada Kuadran IV ini atribut/pernyataan ini memiliki tingkat harapan rendah menurut pegawai, akan tetapi pegawai memiliki persepsi yang baik, sehingga dianggap berlebihan oleh pegawai. Hal ini menunjukan bahwa atribut/pernyataan yang memengaruhi kepuasan kerja pegawai dinilai berlebihan dalam pelaksanaannya. Kondisi ini disebabkan pegawai menganggap tidak terlalu penting/kurang diharapkan terhadap adanya atribut/pernyataan tersebut, akan tetapi pelaksanaanya dilakukan dengan baik sekali.

\section{HASIL DAN PEMBAHASAN}

Dari 105 orang responden yang diberikan kuesioner, hanya 93 orang atau 89,52 persen yang mengisi kuesioner secara lengkap.Jika dilihat dari jenis kelamin pada Gambar 2, jumlah responden yang mengisi kuesioner terdiri dari 59 orang (63 persen) pria dan 34 orang $37 \%$ wanita. Dalam organisasi ini lebih didominasi oleh pegawai pria.

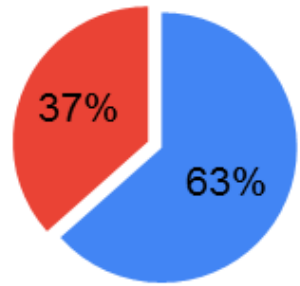

Gambar 2. Proporsi Responden Berdasarkan Jenis Kelamin

Jika dilihat berdasarkan usia responden didominasi oleh pegawai usia muda. Jumlah responden yang mengisi kuesioner menurut usia terdiri dari $64 \%$ berusia 22 sampai 35 tahun, usia 36 sampai 50 tahun $24 \%$, dan yang berusia 50 tahun ke atas $12 \%$. Proporsi ini digambarkan dalam Gambar 3 .

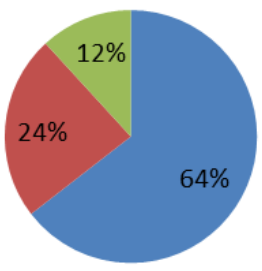

21 s.d. 35 Tahun

- 36 s.d. 50 Tahun

- $>50$ Tahun

Gambar 3. Proporsi Responden Berdasarkan Usia

Jika dilihat berdasarkan golongan pegawai, proporsi responden paling banyak adalah pegawai golongan III yaitu sebanyak 54 orang dari 94 orang responden. Sedangkan proporsi terkecil adalah golongan IV-d yang merupakan para pimpinan. Responden menurut golongan digambarkan pada Gambar 4. 


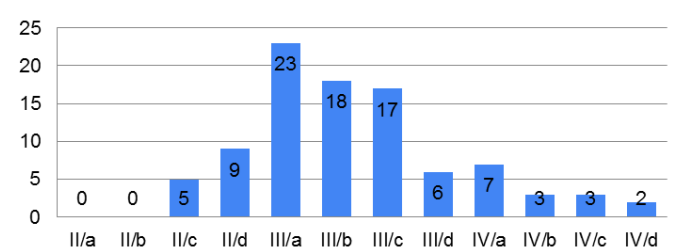

Gambar 4. Proporsi Responden Berdasarkan Golongan

Jika dilihat menurut kelas jabatan poporsi responden menurut jenis jabatan paling banyak adalah jabatan pelaksana sebanyak 74 persen. Proporsi terendah adalah eselon 3 sebesar 2 persen. Proorsi responden menurut jabatan digambarkan pada Gambar 5.

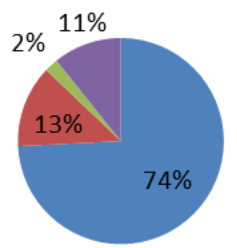

- Pelaksana
- Eselon IV
— Eselon III
- Fungsional Widyaiswara

Gambar 5. Proporsi Responden Berdasarkan Jabatan

\section{Analisis Gap}

Untuk melakukan analisis Gap ini, peneliti mengukur tingkat kesesuaian. Tingkat kesesuaian adalah hasil perbandingan skor persepsi dengan skor yang diharapkan. Metode ini bertujuan untuk mengetahui tingkat kesesuaian antara persepsi variable kepuasan dengan harapan pegawai PPSDM. Atau untuk mengetahui seberapa besar pegawai PPSDM merasa puas terhadap kinerja organisasi dalam memberikan kepuasan kerja pegawai. Hasil analisis data telah menghasilkan tingkat kesesuaian yang disajikan pada Tabel 1.

1. Terdapat empat item yang tingkat kesesuaian kepuasan kerja pegawai yang lebih besar dari
$100 \%$, yang memberikan kepuasan kerja yang melebihi apa yang dianggap penting oleh pegawai atau pelayanan sangat memuaskan. Keempat item tersebut adalah pada item rekan kerja 2 yaitu merasakan pengakuan keterlibatan pegawai dalam tim berja, item rekan kerja 3 yaitu adanya metode penyelesaian konflik oleh lembaga dan item 4 rekan kerja yaitu adanya kesempatan memberikan usulan, dan item supervisi 6 yaitu atasan memberikan pujian dan umpan balik dan dukungan dalam bekerja.

2. Terdapat 25 item lainnya yang tingkat kesesuaian kepuasan kerja pegawai yang lebih kecil dari 100\%. Artinya organisasi memberikan kepuasan kerja yang kurang memenuhi apa yang dianggap penting oleh pegawai atau pelayanan belum memuaskan. Tingkat kesesuaian dibawah $100 \%$ ini masuk dalam kategori antara 66-99\% yaitu pegawai kurang puas. Dari 25 Item tersebut item yang tingkat kesesuaian yang paling kecil adalah pada item kuesioner 5 pada pekerjaan itu sendiri yaitu beban kerja tidak sesuai dengan porsi dan kemampuan dengan nilai 92,03\%.

3. Terdapat sembilanitem yang memiliki Gap tertinggi (di atas -0,25 ) adalah item Pekerjaan 5 (beban kerja sesuai porsi dan kemampuan) dengan Gap -0,33, pekerjaan 1 (lingkungan fisik) dengan Gap -32, promosi 2 (penghargaan atas prestasi kerja) dengan Gap -0,26, supervisi 2 (atasan memberikan solusi) dengan Gap -0,26, pekerjaan 2 (dukungan fasilitas di tempat kerja) dengan Gap -0,26, pekerjaan 8 (kejelasan pola kerja) dengan Gap -0,26, supervisi 1 (atasan memberikan masukan) Gap -0,25, supervisi 3 (atasan adil dan menghargai) dengan Gap -0,25,

supervisi 4 (adil menilai prestasi kerja) dengan Gap -0,25. Dilihat dari 9 item ini yang yang paling bermasalah dalam kepuasan kerja pegawai adalah pada faktor pekerjaan itu sendiri, promosi, dan faktor supervisi

Tabel 1. Tingkat Kesesuaian Responden

\begin{tabular}{|c|c|c|c|c|c|c|c|c|}
\hline No. & Item & $\begin{array}{c}\text { Bobot } \\
\text { Harapan }\end{array}$ & $\begin{array}{c}\text { Bobot } \\
\text { Persepsi }\end{array}$ & $\begin{array}{c}\text { Mean } \\
\text { Harapan }\end{array}$ & $\begin{array}{c}\text { Mean } \\
\text { Persepsi }\end{array}$ & Gap & $\begin{array}{c}\text { Tingkat } \\
\text { Kesesuaian }\end{array}$ & Rerata \\
\hline 1 & kompensasi1 & 399 & 382 & 4,29 & 4,11 & $-0,18$ & $95,74 \%$ & \multirow{5}{*}{$\begin{array}{l}95,41 \% \\
94,99 \%\end{array}$} \\
\hline 2 & kompensasi2 & 402 & 384 & 4,32 & 4,13 & $-0,19$ & $95,52 \%$ & \\
\hline 3 & kompensasi 3 & 397 & 377 & 4,27 & 4,05 & $-0,22$ & $94,96 \%$ & \\
\hline 4 & promosi1 & 350 & 337 & 3,76 & 3,62 & $-0,14$ & $96,29 \%$ & \\
\hline 5 & promosi2 & 380 & 356 & 4,09 & 3,83 & $-0,26$ & $93,68 \%$ & \\
\hline 6 & rekan1 & 402 & 399 & 4,32 & 4,29 & $-0,03$ & $99,25 \%$ & \multirow[b]{6}{*}{$99,37 \%$} \\
\hline 7 & rekan2 & 383 & 386 & 4,12 & 4,15 & 0,03 & $100,78 \%$ & \\
\hline 8 & rekan3 & 390 & 400 & 4,19 & 4,30 & 0,11 & $102,56 \%$ & \\
\hline 9 & rekan4 & 388 & 393 & 4,17 & 4,23 & 0,05 & $101,29 \%$ & \\
\hline 10 & rekan5 & 393 & 389 & 4,23 & 4,18 & $-0,04$ & $98,98 \%$ & \\
\hline 11 & rekan6 & 400 & 384 & 4,30 & 4,13 & $-0,17$ & $96,00 \%$ & \\
\hline
\end{tabular}




\begin{tabular}{llllllll}
\hline 12 & rekan7 & 395 & 382 & 4,25 & 4,11 & $-0,14$ & $96,71 \%$ \\
\hline 13 & supervisi1 & 394 & 371 & 4,24 & 3,99 & $-0,25$ & $94,16 \%$ \\
\hline 14 & supervisi2 & 402 & 378 & 4,32 & 4,06 & $-0,26$ & $94,03 \%$ \\
\hline 15 & supervisi3 & 402 & 379 & 4,32 & 4,08 & $-0,25$ & $94,28 \%$ \\
\hline 16 & supervisi4 & 400 & 377 & 4,30 & 4,05 & $-0,25$ & $94,25 \%$ \\
\hline 17 & supervisi5 & 393 & 379 & 4,23 & 4,08 & $-0,15$ & $96,44 \%$ \\
\hline 18 & supervisi6 & 370 & 375 & 3,98 & 4,03 & 0,05 & $101,35 \%$ \\
\hline 19 & supervisi7 & 371 & 356 & 3,99 & 3,83 & $-0,16$ & $95,96 \%$ \\
\hline 20 & supervisi8 & 394 & 387 & 4,24 & 4,16 & $-0,08$ & $98,22 \%$ \\
\hline 21 & pekerjaan1 & 380 & 350 & 4,09 & 3,76 & $-0,32$ & $92,11 \%$ \\
\hline 22 & pekerjaan2 & 393 & 369 & 4,23 & 3,97 & $-0,26$ & $93,89 \%$ \\
\hline 23 & pekerjaan3 & 401 & 394 & 4,31 & 4,24 & $-0,08$ & $98,25 \%$ \\
\hline 24 & pekerjaan4 & 393 & 364 & 4,23 & 3,91 & $-0,31$ & $92,62 \%$ \\
\hline 25 & pekerjaan5 & 389 & 358 & 4,18 & 3,85 & $-0,33$ & $92,03 \%$ \\
\hline 26 & pekerjaan6 & 395 & 376 & 4,25 & 4,04 & $-0,20$ & $95,19 \%$ \\
\hline 27 & pekerjaan7 & 383 & 366 & 4,12 & 3,94 & $-0,18$ & $95,56 \%$ \\
\hline 28 & pekerjaan8 & 385 & 361 & 4,14 & 3,88 & $-0,26$ & $93,77 \%$ \\
\hline 29 & pekerjaan9 & 390 & 371 & 4,19 & 3,99 & $-0,20$ & $95,13 \%$ \\
\hline
\end{tabular}

Tabel 2. Peringkat Rerata Tingkat Kesesuaian

\begin{tabular}{llll}
\hline $\begin{array}{l}\mathrm{N} \\
\mathrm{O}\end{array}$ & Faktor & $\begin{array}{l}\text { Rerata } \\
\text { dalam } \\
\%\end{array}$ & $\begin{array}{l}\text { Keteran } \\
\text { gan }\end{array}$ \\
\hline 1 & Rekan Kerja & 99,37 & $\begin{array}{l}\text { kurang } \\
\text { puas }\end{array}$ \\
\hline 2 & Supervisi & 96,09 & $\begin{array}{l}\text { kurang } \\
\text { puas }\end{array}$ \\
\hline 3 & Kompensasi & 95,41 & $\begin{array}{l}\text { kurang } \\
\text { puas }\end{array}$ \\
\hline 4 & Promosi & 94,99 & $\begin{array}{l}\text { kurang } \\
\text { puas }\end{array}$ \\
\hline 5 & $\begin{array}{l}\text { Pekerjaan } \\
\text { itu sendiri }\end{array}$ & 94,28 & $\begin{array}{l}\text { kurang } \\
\text { puas }\end{array}$ \\
\hline
\end{tabular}

Tingkat kepuasan kerja rata-rata

pegawai PPSDM96,03

Jika dilihat secara rerata tingkat kesesuaian per faktor yang memengaruhi kepuasan kerja disajikan pada Tabel 2 dimana tingkat kepuasan pegawai PPSDM adalah 96,03\% atau masuk dalam golongan di antara 66\%-99\% atau masuk dalam kategori kurang puas. Data tentang rerata kesesuaian, eringkat kesesuaian, dan Tingkat kepuasan kerja pegawai PPSDM disajikan pada Tabel 2.

Setelah tingkat kesesuaian diukur, tahap selanjutnya adalahmenganalisis lebih lanjut dengan memasukkan hasil yang diperoleh ke dalam diagram kartesius. Diagram kartesius adalah suatu bangun yang terdiri dari atas empat bagian yang dibatasi oleh dua buah garis yang berpotongan tegak lurus pada titik $(\mathrm{X}, \mathrm{Y})$. Garis $\mathrm{X}$ merupakan rata-rata tingkat pelaksanaan atau kepuasan kerja pegawai PPSDM atas seluruh faktor atau atribut.

Garis Y adalah rata-rata dari skor rata-rata tingkat kepentingan atau harapan seluruh faktor yang mempengaruhi kepuasan kerja pegawai PPSDM. Diagram Kartesius disajikan pada Gambar 6.

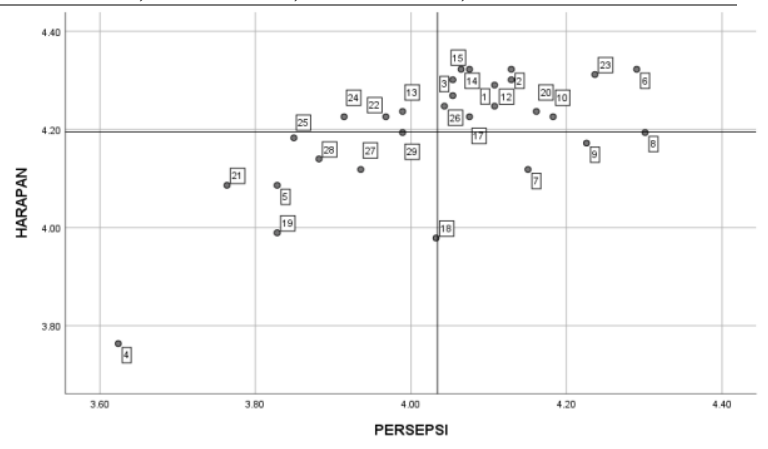

Gambar 6. Diagram Kartesius Hasil Penelitian

Adapun penjelasan dari diagram kartesius dibagi menjadi empat kuadran yaitu

1. Peta Kuadran I (Prioritas Utama)

Atribut kepuasan kerja pegawai PPSDM yang berada pada kuadran ini adalah atribut 13 , 22, 24, dan 25. Atribut 13 berarti masukan dari atasan untuk memperbaiki kinerja masih kurang. Atribut 22 adalah Belum tersedianya dukungan fasilitas di tempat kerja (ruangan, komputer, mesin cetak, dll). Atribut 24 adalah Prosedur kerja di lapangan belum cukup jelas, dan atribut 25 adalah pegawai memperoleh beban kerja yang belum sesuai dengan porsi dan kemampuan.

Item yang masuk pada Kuadran I ini memuat atribut/pernyataan yang dianggap penting oleh pegawai namun atribut/pernyataan tersebut belum sesuai dengan harapan pegawai. Tingkat kinerja dari atribut/pernyataan tersebut lebih rendah daripada tingkat harapan pegawai terhadap atribut/pernyataan tersebut. Atribut/pernyataan yang terdapat dalam kuadran ini menjadi prioritas untuk ditingkatkan kinerjanya supaya kepuasan kerja pegawai dapat memuaskan.

2. Peta Kuadran II (Pertahankan Prestasi)

Atribut kepuasan kerja yang masuk dalam kuadran II ini adalah atribut nomor $1,2,3,6,10,12,15,20,23$, dan 26.Atribut 1,2, dan 3 adalah atribut kompensasi. yaitu sistem distribusi gaji,besaran gaji dan tunjangan sudah 
memuaskan. Atribut 6 adalah diperhitungkannya aspek kreativitas dan daya cipta pegawai dalam promosi. Atribut 10,12 dan adalah adalah kesempatan untuk memberikan usulan kepada rekan rekan memuaskan. Atribut 15 adalah adanya kepedulian dan keadilan dari atasan. Atribut 20 adalah atribut kesempatan untuk mengembangkan karir oleh atasan. Atribut 23 adalah kondisi fisik kerja yang aman dan jarang terjadi kecelakaan. dan atribut 26 adalah atribut untuk kesempatan pegawai untuk memanfaatkan kemampuan dan keahlian menyelesaikan pekerjaan.

Atribut yang masuk pada kuadrant II ini memiliki tingkat harapan yang tinggi dan persepsi yang tinggi juga. Hal ini menunjukkan bahwa atribut/pernyataan tersebut penting untuk kepuasan kerja pegawai. Atribut/pernyataan dalam kuadran II ini wajib dipertahankan untuk waktu yang akan datang karena dianggap sangat penting/diharapkan dan hasilnya sangat memuaskan.

\section{Peta Kuadran III (Berlebihan)}

Atribut yang masuk dalam kuadran ini adalah 7,8,9 dan 17, 18. Atribut 7,8 dan 9 adalah atribut kerja sama antar rekan kerja, pengakuan partisipasi, dan adanya metode penyelesaian konflik dalam tim. Atribut 17 dan 18 adalah atribut untuk atasan yang mau mendengarkan masukan dan memberikan pujian ke pegawai.

Item yang masuk pada Kuadran III ini memiliki tingkat harapan rendah menurut pegawai, akan tetapi pegawai memiliki persepsi yang baik, sehingga dianggap berlebihan oleh pegawai. Hal ini menunjukkan bahwa atribut/pernyataan yang memengaruhi kepuasan kerja pegawai dinilai berlebihan dalam pelaksanaannya. Kondisi ini disebabkan pegawai menganggap tidak terlalu penting/kurang diharapkan terhadap adanya atribut/pernyataan tersebut, akan tetapi pelaksanaanya dilakukan dengan baik sekali.

4. Peta Kuadran IV (Prioritas Rendah)

Atribut yang masuk pada kuadran IV ini adalah atribut 4,5,19,21,27,28, dan 29. Atribut 4 dan 5 adalah atribut formasi dan prestasi kerja untuk promosi. Atribut 19 adalah atribut masukan, bantuan dan penilaian dari atasan atau supervisi. Atribut 21 adalah atribut untuk kondisi fisik kerja atau lingkungan fisik kerja. Atribut 27,28 dan 29 adalah atribut kebebasan pegawai dalam menyelesaikan pekerjaan, kejelasan prosedur dan adanya feedback hasil pekerjaan.

Item yang masuk pada kuadranIVini dianggap kurang penting oleh pegawai dan pada kenyataannya persepsi pegawai tidak terlalu istimewa/biasa saja. Maksudnya atribut/pernyataan yang terdapat dalam kuadran ini memiliki tingkat harapan yang rendah dan persepsi pegawai juga rendah. Perbaikan terhadap atribut/pernyataan yang masuk dalam kuadran ini perlu dipertimbangkan kembali dengan melihat atribut/pernyataan yang mempunyai pengaruh terhadap manfaat yang dirasakan oleh pegawai itu besar atau kecil dan juga untuk mencegah atribut/pernyataan tersebut bergeser ke kuadran I.

Penggunaan analisis gap dan kuadran memberikan masukan yang cukup baik untuk melihat perbedaan antara harapan dan realita yang dihadapi karyawan sebagai penggunaan analisis gap pada penelitian Febriyanto(2011). Dari sisi hasil penelitian ini senada dengan penelitian Sirajuddin, dkk(2020)kondisi lingkungan kerja yangnyaman, pemberian insentif sesuai hasil produksi, dan suasana kerja yang nyaman dapat meningkatkan kepuasan karyawan.

Dalam artikel ini, penulis hanya menggunakan analisis gap dan kuadran, tidak menggunakan analisis lanjutan menggunakan AHP dalam melihat secara mendalam item yang membentuk kepuasan kinerja sebagaimana yang dilakukan Setyowati (2013). Penggunaan analisis gap dan kuadran ini hanya membandingkan antara harapan dan realita yang dialami oleh responden.

\section{KESIMPULAN}

Berdasarkan pembahasan di atas terdapat beberapa kesimpulan yang didapat. Tingkat kepuasan pegawai PPSDM masuk dalam kategori kurang puas yaitu pada nilai $96,03 \%$ atau berada pada kategori $66 \%$ sampai dengan 99\%. Tingkat kesesuaian kepuasan kerja pegawai $100 \%$, berarti organisasi memberikan kepuasan kerja yang memenuhi apa yang dianggap penting oleh pegawaiatau pelayanan telah memuaskan.Faktor kompensasi relatif sudah memberikan kepuasan kepada pegawai. Faktor ini merupakan faktor penting bagi pegawai dan menurut persepsi pegawai sudah relatif memuaskan.Faktor promosi relatif kurang memuaskan pegawai dengan tingkat kesesuaian 94,99\%. Namun faktor promosi ini dalam diagram kartesius masuk di kuadran IV yaitu prioritas rendah.Faktor rekan kerja dengan tingkat kesesuaian 99,37\% merupakan faktor yang paling tinggi yang menunjang kepuasan kerja pegawai. Pegawai menganggap rekan kerja penting dan persepsi terhadap rekan kerja memuaskan.

Faktor atasan atau supervisi mendapat nilai 96,09\% dan berada pada posisi kedua yang memuaskan pegawai. Pegawai menganggap faktor atasan atau supervisi penting dan persepsi pegawai relatif memuaskan.Faktor pekerjaan itu sendiri dengan rerata kesesuaian 94,28\% menjadi faktor yang paling rendah dalam menunjang kepuasan pegawai PPSDM. Atribut yang menjadi masalah 
dalam pekerjaan itu sendiri adalah belum tersedianya dukungan fasilitas di tempat kerja (ruangan, komputer, mesin cetak, dll), prosedur kerja di lapangan belum cukup jelas,dan pegawai memperoleh beban kerja yang belum sesuai dengan porsi dan kemampuan. Pekerjaan itu sendiri dianggap tinggi oleh pegawai dan persepsi pegawai adalah sedang.

Adapun saran yang dapat diberikan adalah Agar PPSDM dan BPPK secara keseluruhan melakukan evaluasi terhadap kepuasan kerja pegawai PPSDM. Selanjutnya memberikan perhatian untuk meningkatkan kepuasan kerja pegawai sampai diatas $100 \%$. Kepuasan kerja pegawai akan berpengaruh positif terhadap kinerja organisasi.PPSDM dan BPPK agar mempercepat fungsionalisasi pegawai sebagai alternatif untuk promosi, karena jabatan struktural yang terbatas.PPSDM dan BPPK agar meningkatkan kemampuan pejabat struktural dalam bidang mengelola organisasi. Kelemahan dalam mengelola organisasi akan berakibat terhadap kesulitan pegawai dalam melaksanakan tugasnya. PPSDM dan BPPK melakukan reviu terhadap setiap pekerjaan pegawai agar pegawai dapat bekerja dengan lebih leluasa. Fasilitas kerja agar dilengkapi sesuai dengan kebutuhan, prosedur kerja diperjelas, dan beban kerja disesuaikan dengan kapasitasnya. Terhadap masingmasing pegawai diberikan pemberdayaan dalam menyelesaikan tugasnya, agar tidak terlalu tergantung kepada atasan.

\section{REFERENSI}

Ardana, I. K., Mujiati, N. W., \& Utama, I. W. (2012). Manajemen Sumber Daya Manusia. Yogyakarta: Graha Ilmu.

Batemen, \& Snelt. (2015). Management. 11Th Edition. Singapore: McGraw-Hill.

Febriyanto. (2011). Analisis Gap Harapan Dan Kinerja Berdasarkan Persepsi Pengunjung Taman Nasional Way Kambas di Lamung Timur. Jurnal Manajemen dan Bisnis, 2(1), 53-68,

DOI: http://dx.doi.org/10.36448/jmb.v2i1.4 8.

Mas'ud, F. (2004). Survai diagnosis organisasional. Semarang: Badan Penerbit Universitas Diponegoro.

Muri, Y. (2014). Metode Penelitian, edisi pertama. Jakarta: Prenadamedia Group.
Mutiara, P. (2004, ). Manajemen Sumber Daya Manusia. Bogor: Ghalia Indonesia.

Sedarmayanti. (2001). Sumber Daya Manusia dan Produktivitas Kerja. Bandung: Mandar Maju.

Setyowati, S. (2013). Analisa Evaluasi Kinerja Pegawai untuk Promosi Jabatan Menggunkan Model Hybrid Gap-Analysis AHP. Seminar Nasional Aplikasi Teknologi Informasi (SNATI), (hal. 22-30). Yogyakarta, https://journal.uii.ac.id/Snati/article/view/3 016.

Sirajuddin, Sari, C. A., \& Hasanuddin. (2020). Mengukur tingkat kepuasan karyawan pada perusahaan reparasi mesin industri dengan menggunakan metode importance performance analysis. Teknika: Jurnal Sains dan Teknologi, 16(1), 113-121, DOI: http://dx.doi.org/10.36055/tjst.v16i1.8 042.

Siregar, S. (2013). Metode Penelitian Kuantitatif. Jakarta: Penerbit Kencana.

Stephen, .. R., \& Judge, T. A. (2015). Organizational Behaviour. 16th Edition. England: Pearson.

Sudriamunawar, H. (2006). Kepemimpinan, peran serta dan produktivitas. Bandung: Mandar Maju.

Sugiyono. (2013). Metode Penelitian Pendidikan Pendekatan Kuantitatif,. Kualitatif, dan R\&D. . Bandung: Alfabeta.

Uma, S., \& Bougie, R. ( 2010). Reseach Methods For Business. John Wiley \& Sons: United Kingdom. 